\title{
Dual Mechanism of Toxicity for Extracellular Injection of Tau Oligomers versus Monomers in Human Tau Mice
}

\author{
Giusi Manassero $^{\mathrm{b}, \mathrm{c}, \mathrm{d}}$, Michela Guglielmotto ${ }^{\mathrm{a}, \mathrm{b}, \mathrm{c}}$, Debora Monteleone $^{\mathrm{a}, \mathrm{b}}$, Valeria Vasciaveo $^{\mathrm{a}, \mathrm{b}}$, \\ Olena Butenko ${ }^{\mathrm{a}, \mathrm{b}}$, Elena Tamagno ${ }^{\mathrm{a}, \mathrm{b}}$, Ottavio Arancio ${ }^{\mathrm{e}}$ and Massimo Tabaton ${ }^{\mathrm{c}, *}$ \\ ${ }^{a}$ Department of Neuroscience, University of Torino, Torino, Italy \\ ${ }^{\mathrm{b}}$ Neuroscience Institute of Cavalieri Ottolenghi Foundation (NICO), University of Torino, Torino, Italy \\ ${ }^{\mathrm{c}}$ Department of Internal Medicine and Medical Specialties (DIMI), Unit of Geriatric Medicine, \\ University of Genova, Genova, Italy \\ ${ }^{\mathrm{d}}$ IRCS San Martino-IST, University of Genova, Genova, Italy \\ ${ }^{\mathrm{e}}$ Department of Pathology and Cell Biology, Taub Institute for Research on Alzheimer's Disease \\ and the Aging Brain, Columbia University, New York, NY, USA
}

Accepted 16 May 2017

\begin{abstract}
The mechanism of tau toxicity is still unclear. Here we report that recombinant tau oligomers and monomers, intraventricularly injected in mice with a pure human tau background, foster tau pathology through different mechanisms. Oligomeric forms of tau alter the conformation of tau in a paired helical filament-like manner. This effect occurs without tau hyperphosphorylation as well as activation of specific kinases, suggesting that oligomers of tau induce tau assembly through a nucleation effect. Monomers, in turn, induce neurodegeneration through a calpain-mediated tau cleavage that leads to accumulation of a $17 \mathrm{kDa}$ neurotoxic peptide and induction of apoptotic cell death.
\end{abstract}

Keywords: Alzheimer's disease, hTau mice, paired helical filaments, tau protein

\section{INTRODUCTION}

Aggregates of amyloid- $\beta(A \beta)$ and tau proteins are central events in Alzheimer's disease (AD) pathology. According to the amyloid hypothesis, the physical and chemical changes of tau leading to its polymerization are initiated by $\mathrm{A} \beta$ accumulation [1]. Within this context, we have recently observed that monomeric preparations of $A \beta_{1-42}$ are capable of altering the aggregation and conformation of tau protein when injected in mice with a pure human tau (hTau) background, through activation of phosphokinases as well as impairment of tau degradation [2].

\footnotetext{
${ }^{*}$ Correspondence to: Prof. Massimo Tabaton, Department of Internal Medicine and Medical Specialities (DIMI) Viale Benedetto XV, 6,16132, Genova, Italy. Tel./Fax: +39 0103537064 ; E-mail: mtabaton@neurologia.unige.it.
}

However, $A \beta$ is not responsible for tau changes in tauopathies. In $\mathrm{AD}$, tau is likely to contribute to its spreading from cell to cell. Hyperphosphorylation, decreased tubulin binding, and increase of homologous isoforms are known mechanisms of tau assembly [3]. In addition, a nucleation effect of tau small aggregates on the progression of tau pathology is suspected, because abnormally conformed tau spreads from cell to cell in a prion-like manner [4]. Here we report that oligomers and monomers of tau, intracerebroventricularly (ICV) injected into hTau mice, foster tau pathology with different mechanisms. Whereas oligomers mediate the aggregation of tau through a nucleation effect, regardless of the action of tau specific kinases, monomers produce a toxic cleavage of tau through calpain activation and induction of apoptotic cell death. 


\section{MATERIALS AND METHODS}

\section{Animals}

hTau mice (Mapt ${ }^{\text {tm1(EGFP)Klt }}$ Tg(MAPT) 8cPdav/J; \#004808, Jackson Laboratory) were crossed with tau knock-out (KO) mice (Mapt tm1(EGFP)Klt/J; \#0047 79, Jackson Laboratory), to obtain pregnant females carrying hTau fetuses as described by Andorfer and colleagues [5]. Mice were genotyped by PCR assay using the following primers: human tau transgene (forward 5'-ACTTTGAACCAGGATGGCTGAGC CC-3', reverse 5'-CTGTGCATGGCTGTCCCTACC TT-3'), mouse tau gene (forward 5'-CTCAGCATC CCACCTGTAAC-3', reverse 5'-CCAGTTGTGTAT GTCCACCC-3'), and disrupted tau gene (forward 5'-CAGGCTTTGAACCAGTATGG-3', reverse 5'TGAACTTGTGGC CGTTTACG-3'). Mice were maintained on a Swiss Webster/129/SvJae/C57BL/6 background [5]. Animals were kept on a $12 \mathrm{~h}$ light/ dark cycle with food and water available ad libitum. All experimental procedures on live animals were performed under the supervision of a licensed veterinarian, according to: 1) European Communities Council Directive (November 24,1986; 86/609/ EEC); 2) Italian Ministry of Health and University of Torino's institutional guidelines on animal welfare (DL 116/92 on Care and Protection of living animals undergoing experimental or other scientific procedures; authorization No. 17/2010-B, June 30, 2010); and 3) ad hoc Ethical Committee of the University of Turin (http://www.unito.it/unitoWAR/page/istitu zionale/ricerca1/Ricerca_comitato1).

For our experimental procedures we used 6-8 animals for each group.

\section{Intracerebroventricular injections}

Under isoflurane $\mathrm{O}_{2} / \mathrm{N}_{2} \mathrm{O}$ anesthesia, hTau mice (male, 2 months of age) were ICV injected with $1 \mu \mathrm{l}$ tau peptides $(22.95 \mu \mathrm{g} / \mathrm{ml})$ or artificial cerebrospinal fluid (ACSF) for $3 \mathrm{~h}$ or 4 days. Coordinates used for injection were: anteroposterior, $-0.5 \mathrm{~mm}$; lateral, $1.2 \mathrm{~mm}$ relative to bregma; and dorsoventral, $1.7 \mathrm{~mm}$ from the dural surface. The method was validated by injecting one mouse with Trypan blue $(1 \mu \mathrm{l})$.

\section{Tau preparation}

Preparation of recombinant tau was performed as previously described [6]. Briefly, the cDNA for tau
4R/2N was a gift of Dr. Furukawa (University of Yokohama, Japan) [7]. The plasmid was transfected in Escherichia coli (Rosetta), and cells were streacked on LB agar ampicillin plates and a single colony was picked and grown overnight in LB broth with glucose and $100 \mathrm{mg} / \mathrm{ml}$ carbenicillin. Protein expression was induced with $1 \mathrm{mM}$ IPT for $8 \mathrm{~h}$ at which time cells were pelleted at $4{ }^{\circ} \mathrm{C}$ by centrifugation at $6,000 \mathrm{~g}$ and stored overnight at $-80^{\circ} \mathrm{C}$. Cells were then lysed and the construct purified as previously described [6]. Tau was monomerized by treatment with $5 \mathrm{mM}$ dithiothreitol (DTT) and $5 \mathrm{mM}$ EDTA. Tau was oligomerized through introduction of disulfide bonds via incubation with $1 \mathrm{mM} \mathrm{H}_{2} \mathrm{O}_{2}$ at room temperature for $20 \mathrm{~h}$. Following oligomerization, tau was buffer exchanged to remove excess chemicals. Any insoluble material was removed by ultracentrifugation at $110,000 \mathrm{~g}$ at $4^{\circ} \mathrm{C}$ for $30 \mathrm{~min}$. Tau protein concentration was determined from the absorption at $280 \mathrm{~nm}$ with an extinction coefficient of $7450 \mathrm{~cm}^{-1}$ $\mathrm{M}^{-1}$ and expressed in $\mu \mathrm{g} / \mathrm{ml}$.

\section{Antibodies and immunoblot analysis}

Immunoblot analysis were performed using the following antibodies: MC1 (kind gift from Dr. P Davies, Albert Einstein College of Medicine, New York, 1:500); Tau5 (Millipore, \#577801, 1:500); AT8 (Innogenetics, \#90206, 1 : 500); Tau 46 (Abcam, \#22261, 1 : 1000), TaupS396 (Invitrogen, \#44752G, $1:$ 1000); TaupS262 (Invitrogen, \#44750G, $1: 1000$ ); TaupS244 (Invitrogen, \#44764G, $1: 1000$ ); GSK3 $\alpha$ pY279/ßpY216 (Invitrogen, \#44604G, $1: 1000$ ); GSK3 $\alpha / \beta$ tot $(1: 1000$, Invitrogen, \#44610, $1: 1000)$; GSK3ßpS9 (Novex, \#710100, $1: 1000$ ); pJNK1/2 (Cell Signaling Technology, \#9251, 1 : 500); JNK1/2 (Cell Signaling Technology, \#9252, 1:500); pP38 (Calbiochem, \#506119, 1: 1000); P38 (Calbiochem, \#06123, $1: 1000$ ); pERK1/2 (Cell Signaling Technology, \#43765, 1 : 1000); ERK1/2 (Santa Cruz Biotechnology, Sc-93, 1:1000); calpain 1 (Abcam, ab28258, 1:000); spectrin (Millipore, \#Mab 1622, $1: 500$ ); BAX (Santa Cruz Biotechnology, Sc-493, 1 : 100); Bcl-2 (Santa Cruz Biotechnology, Sc-509, $1:$ 200); Tau 1(Millipore, \#Mab 3420, $1: 500$ ); glyceraldehyde 3-phosphate dehydrogenase (GAPDH) (Millipore, Mab374, 1:3000).

Fresh frozen brains were mechanically homogenized in ice-cold buffer $(25 \mathrm{mM}$ Tris- $\mathrm{HCl} \mathrm{pH} 7.4$, $150 \mathrm{mM} \mathrm{NaCl}, 1 \mathrm{mM}$ EGTA, $1 \mathrm{mM}$ EDTA, $1 \mathrm{mM}$ PMSF, phosphatase and protease inhibitors) and then 
centrifuged at $10,000 \mathrm{~g}$ for $15 \mathrm{~min}$ al $4^{\circ} \mathrm{C}$ to isolate soluble proteins. Supernatants $(2 \mathrm{mg} / \mathrm{ml}$ solution) were collected and incubated with sarkosyl (1\% final concentration) overnight at $4{ }^{\circ} \mathrm{C}$. The sarkosyl mixtures were then centrifuged in Beckman SW $55 \mathrm{Ti}$ rotor at $35,000 \mathrm{rpm}$ for $1 \mathrm{~h}$ at $4^{\circ} \mathrm{C}$. Pellets were resuspended in $100 \mu \mathrm{l}$ sample buffer to obtain sarkosyl-insoluble proteins. Lysates $(20 \mu \mathrm{g})$ were run on $3-8 \%$ Tris- $\mathrm{HCl}$ gradient PAGE gel (Invitrogen) and then transferred to PVDF membrane. Peroxidaseconjugated secondary antibodies were incubated $1 \mathrm{~h}$ at room temperature and developed with Luminata Forte Western substrate (WBLUF0100, Millipore). Densitometric values were normalized to GAPDH.

\section{Statistical analysis}

Statistical analyses were performed using GraphPad Prism version 4.0 (GraphPad software, San Diego). All values were presented as mean \pm standard error of the mean (SEM). Means were compared by one or two way analysis of variance (ANOVA) with Bonferroni as a post-hoc test.

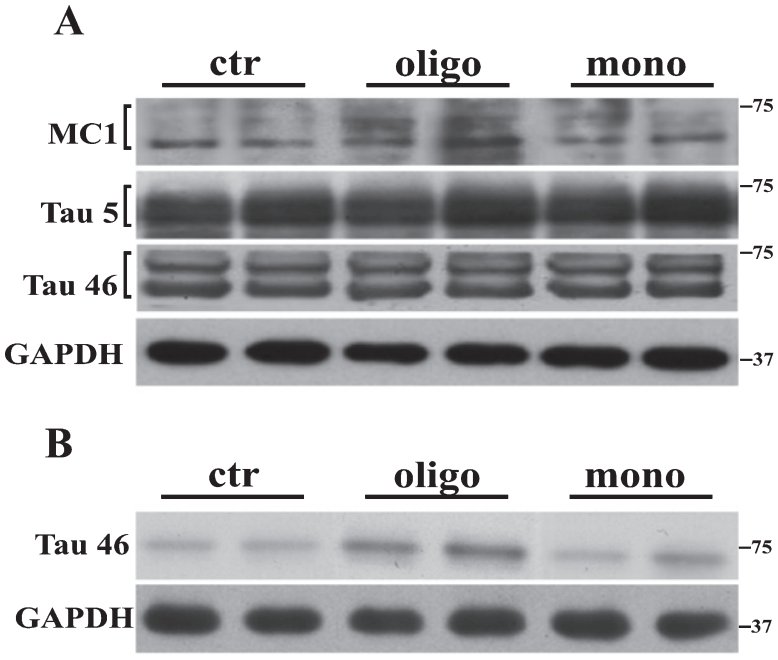

\section{RESULTS}

We performed all experiments by injecting tau monomers or oligomers $(1 \mu \mathrm{l}, 22.95 \mu \mathrm{g} / \mathrm{ml}$, bilaterally), in 2-month-old hTau mice which were sacrificed after $3 \mathrm{~h}$ (unless otherwise stated) for brain harvesting. The results are the average of four identical experiments. Tau peptides were made by Dr. Ottavio Arancio that performed and published the characterization and purity level of oligomeric and monomeric tau peptides [6].

\section{Tau oligomers, but not monomers, induce conformational change of tau protein}

To determine whether tau oligomers (oTau) and monomers (mTau) affect tau conformation, we performed western blotting analysis using the antibody $\mathrm{MC1}$, a conformation-dependent antibody that recognizes an early and pathologic tau found in PHF, but not in normal brain [8]. As shown in Fig. 1A, oTau induced tau protein conformational changes in brains harvested at $3 \mathrm{~h}$ after its injection as revealed

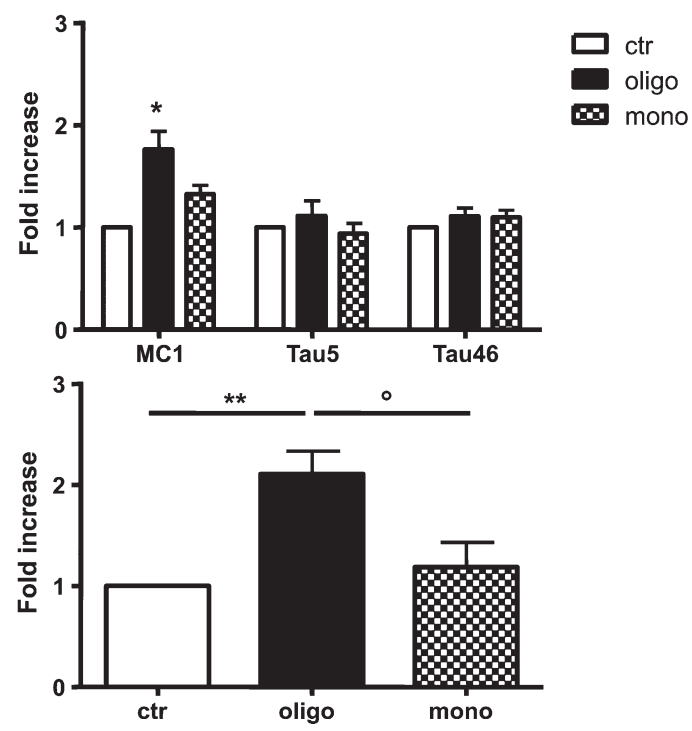

Fig. 1. Tau oligomers, but not monomers, induce a conformational change of tau protein. A) Representative western blot of brain extracts from mice injected with control ACSF solution or tau peptides (ICV for $3 \mathrm{~h}$ ) using a conformational tau antibody (MC1) and total tau antibodies (Tau5 as well as Tau46) for detection. Densitometric quantification shows a significant tau pathological conformational change revealed by $\mathrm{MC} 1$ antibody induced by oligomers, but not by monomers. B) Representative western blot of insoluble tau fraction by sarkosyl detergent technique extracts from mice injected with control ACSF solution or tau peptides (ICV for $3 \mathrm{~h}$ ) using a Tau 46 antibody for detection. Treatment with oligomeric preparations produced a significant increase in immunoreactivity for a band at approximately $75 \mathrm{kDa}$ molecular weight. mTau, in turn, did not produce any significant change in the $75 \mathrm{kDa}$ band. In all cases an antibody raised against GAPDH served as a loading control. The data are mean $\pm \mathrm{SEM},{ }^{*} p<0.05 ;{ }^{* *} p<0.01$ versus control while ${ }^{\circ} p<0.05$ versus mono by one-way ANOVA followed by Bonferroni post hoc test, $n=6$. 
by the significant increase of the corresponding bands of $50-75 \mathrm{kDa}$. The monomeric form of tau was not affected (Fig. 1A). Both preparations did not produce an increase in the levels of total tau as revealed by Tau 5 as well as Tau 46 antibodies (Fig. 1A). The crucial point of the paper is to discriminate between the endogenous tau and the exogenous injected pool. We found that levels of total tau are not significantly different in treated and controls mice. Thus we thought that the concentrations of tau peptides injected (approx. $23 \mathrm{ng}$ ) are below the sensitivity of the method. In any case, we cannot completely exclude that the bands show a mixture of endogenous and exogenous pool but we think that the endogenous pool is by far predominant. Therefore we think that the possible presence of the exogenous pool does not invalidate the different effects induced by tau oligomers and monomers.

Consistent with these findings, we observed that only treatment with oTau caused a band at approximately $75 \mathrm{kDa}$ using Tau 46 antibody when we studied the insoluble tau fraction by sarkosyl detergent technique (Fig. 1B).

\section{The oTau mediated conformational change of tau is not mediated by its hyperphosphorylation}

Whether tau hyperphosphorylation in $\mathrm{AD}$ is a cause of aggregation [9] or not is still controversial [10]. To determine whether oTau modifies the phosphorylation of tau protein, we measured the levels of phosphorylated tau using AT8 antibody through western blotting technique. We found that both oTau and mTau did not modify AT8 immunoreactivity (Fig. 2). The same type of result was observed when we tested the ability of oTau and mTau to promote the phosphorylation at other sites that have been related to

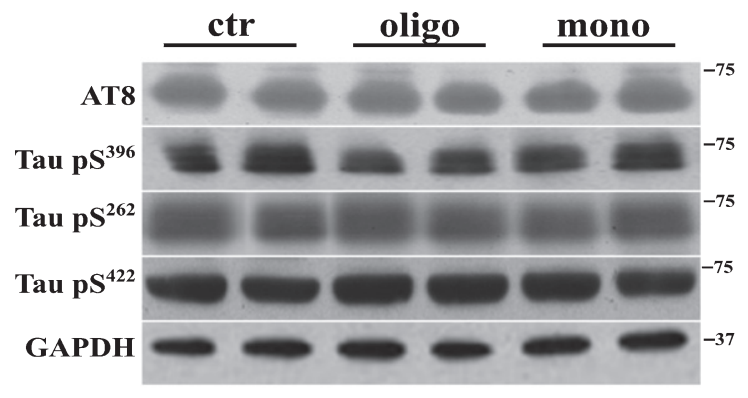

AD pathology. Phosphorylation-sensitive antibodies, such as Tau S396, S422, and S262, did not reveal any change in phosphorylation following oTau or mTau administration (Fig. 2).

To confirm the lack of changes in phosphorylation mediated by tau peptides, we measured levels of kinases that are involved in phosphorylation at these sites. Tau is phosphorylated by phospho-kinases such glycogen synthase kinase $3 \beta$ (GSK3 $\beta$ ), mitogenactivated protein kinase, and cyclin-dependent kinase 5 (CDK5) [3]. We found that the treatment with both oTau and mTau peptides did not modify the levels of these kinases (Fig. 3A-E). Thus we can affirm that oTau peptides induce tau conformational changes regardless of the action of tau specific kinases.

\section{Tau monomers trigger calpain-mediated generation of a 17-kDa neurotoxic tau fragment}

Calpains are calcium-dependent proteases that have been found to be dysregulated in $\mathrm{AD}$ and in many other tauopathies [11, 12]. Calpain-mediated tau cleavage leads to the generation of a $17-\mathrm{kDa}$ neurotoxic tau fragment [13]. Thus, we tested if tau oligomeric as well monomeric preparations injected in hTau mice were able to alter calpain protein levels and produce the toxic fragment. Using western blotting technique, we found that tau monomers, but not oligomers, induced a significant increase of calpain 1 protein levels at $3 \mathrm{~h}$ after the injection (Fig. 4A).

To confirm that the increase of calpain protein levels was followed by a significant increase of its activity, we performed western blotting using a specific spectrin antibody. Spectrin degradation is highly sensitive to calpain activation and considered a good marker for the protease activity [14]. As shown on

Fig. 2. Tau oligomers do not alter the phosphorylation state of tau protein. Representative western blot of brain extracts (20 $\mu \mathrm{g}$ protein) from mice injected with control ACSF solution or tau peptides (ICV for $3 \mathrm{~h}$ ) using antibodies specific for the detection of four pathological tau phosphorylation sites: AT8, pS396, pS262, and pS422. An antibody raised against GAPDH served as a loading control. Densitometric quantification shows that both oTau and mTau were not able to alter the phosphorylation state of tau. The data are mean \pm SEM, $n=6$. 
A

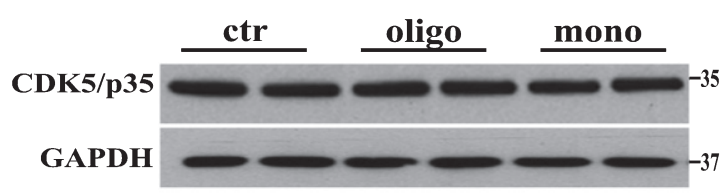

B

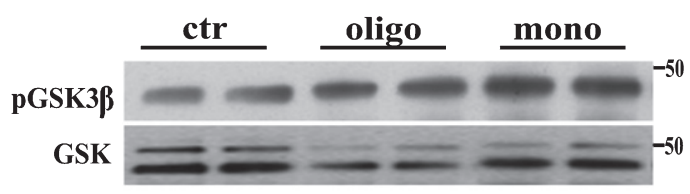

C

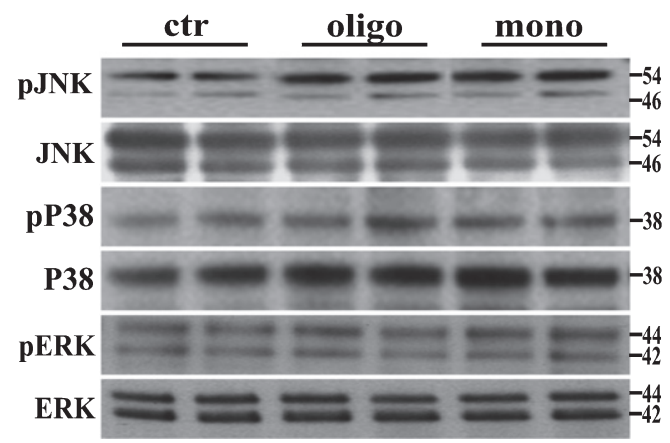




Fig. 3. Tau peptides do not affect the major kinases involved in the regulation of tau protein. Representative western blotting of brain extracts from mice injected with control ACSF solution and tau peptides (ICV for $3 \mathrm{~h}$ ) using CDK5/p35 (A), pGSK3 $\beta$ (B), and pJNK, pP38, and pERK1/2 (C) antibodies for detection. Densitometric quantification shows that the activity of the major kinases involved in the regulation of tau protein is not affected by both oTau and mTau peptides. A) An antibody raised against GAPDH was used as a loading control. B, C) pGSK3 $\beta$, pJNK, pP38, and pERK1/2 levels were standardized against their respective total protein amount. The data are mean $\pm \mathrm{SEM}$, $n=6$.

Fig. 4A, $3 \mathrm{~h}$ after tau monomer injection a strong decrease in full length spectrin protein was observed. Injection with oTau, in turn, did not modify the amount of full length spectrin.

Consistent with the increase in calpain activity after mTau injection, we found the production of a $17 \mathrm{kDa}$ tau fragment detected through the Tau 1 antibody after mTau administration (Fig. 4B). Calpain activation as well as the intrinsic mitochondrial pathway for apoptosis play a key role in neuronal death [15]. Thus, we tested if the production of the calpain1mediated tau fragment was followed by the induction of apoptotic cell death. We measured the protein levels of the proapoptotic effector BAX as well as the antiapoptotic protein $\mathrm{BCl}-2$. The injection of mTau caused a significant increase of BAX protein and a parallel significant decrease of Bcl-2 (Fig. 5A). By contrast, oTau did not produce significant changes in levels of Bcl-2 or Bax (Fig. 5A).
Finally, we tested whether a longer exposure of hTau mice to mTau produces an effect on tau conformation mimicking the effects of oTau. Mice were injected ICV with $1 \mu 122.95 \mu \mathrm{g} / \mathrm{ml}$ mTau and sacrificed 4 days later. As shown on Fig. 5B, we found that mTau did not acquire the ability of changing tau conformation, but maintained the ability to induce neurodegeneration as revealed by a significant increase in Bax protein levels (Fig. 5B).

\section{DISCUSSION}

The aim of the study was to investigate whether and how recombinant monomers as well as oligomers of tau are able to render tau protein prone to aggregation in a PHF-like state and foster tau pathology. To address this issue, we used a mouse model that expresses wild-type human tau at an age when 
A
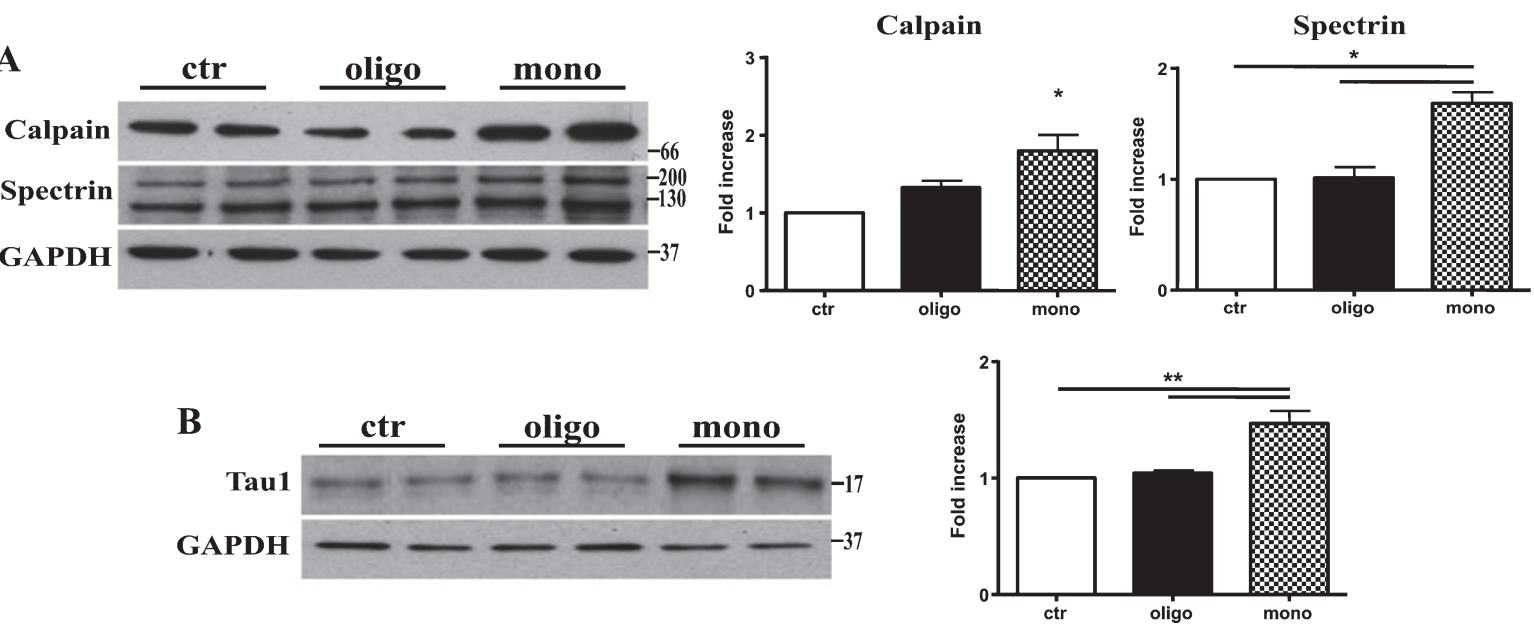

Fig. 4. Tau monomers trigger calpain-mediated generation of a $17 \mathrm{kDa}$ tau fragment. A) Representative western blotting of brain extracts from mice injected with control ACSF solution or tau peptides (ICV for $3 \mathrm{~h}$ ) using calpain 1 and spectrin antibodies for detection. Densitometric quantification shows that the levels of the two enzymes are significantly increased by mTau but not oTau. B) Representative western blotting of brain extracts from mice injected with control ACSF solution or tau peptides (ICV for $3 \mathrm{~h}$ ) using Tau 1 antibody for detection. Only after treatment with monomeric preparations was present a band at approximately $17 \mathrm{kDa}$ molecular weight. In all cases an antibody raised against GAPDH served as a loading control. The data are mean $\pm \mathrm{SEM},{ }^{*} p<0.05 ;{ }^{* *} p<0.01$ versus control by one-way ANOVA followed by Bonferroni post hoc test, $n=6$.
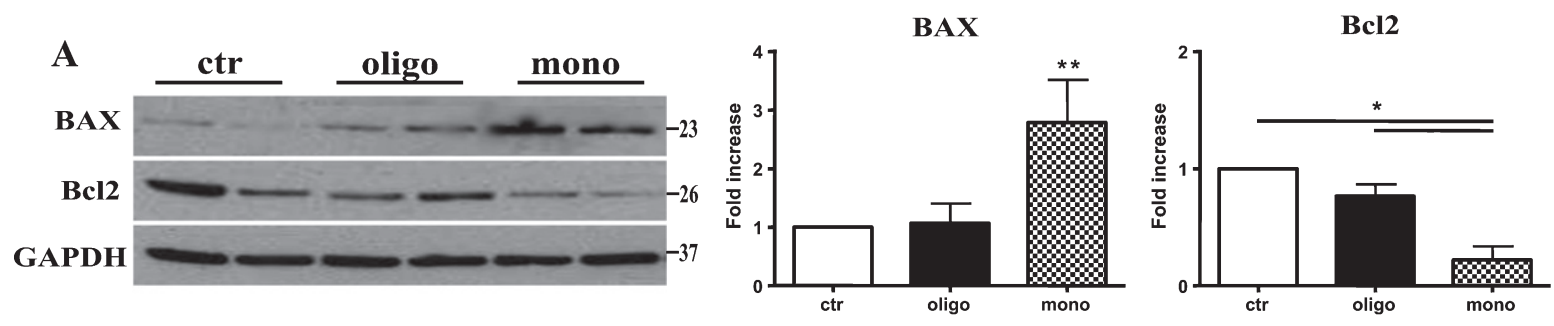

B
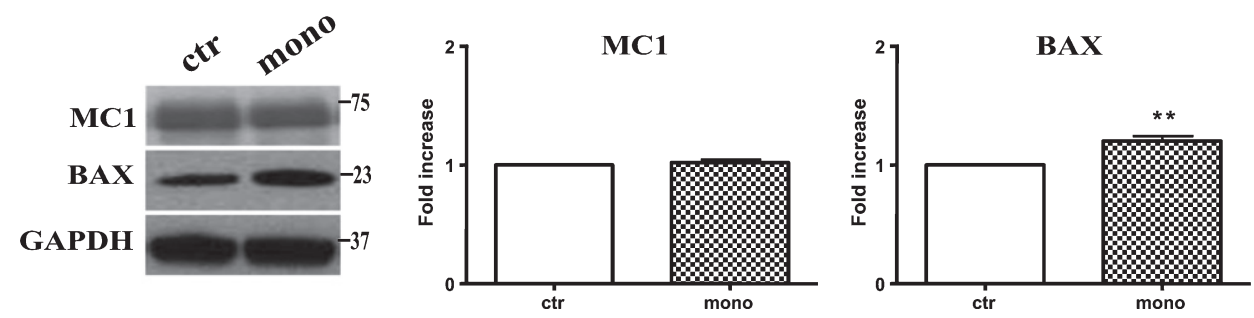

Fig. 5. Tau monomers induce apoptotic cell death and maintain their toxicity also after 4 days treatment without affecting tau conformational changes. A) Representative western blotting of brain extracts from mice injected with control ACSF solution and tau peptides (ICV for $3 \mathrm{~h}$ ) using BAX and Bcl2 antibodies for detection. Densitometric quantification shows that mTau causes a significant increase in proapoptotic protein BAX and a parallel decrease in the antiapoptotic protein Bcl2. By contrast, oTau caused only a significant increase in $\mathrm{n}$ Bax protein levels. B) Representative western blotting of brain extracts from mice injected with control ACSF solution and tau peptides (ICV for 4 days) using MC1 and BAX antibodies for detection. mTau does not modify the pathological conformation of Tau and maintains the ability to mediate apoptotic cell death. In all cases an antibody raised against GAPDH served as a loading control. The data are mean \pm SEM, ${ }^{*} p<0.05$; ${ }^{* *} p<0.01$ versus control by one-way ANOVA followed by Bonferroni post hoc test, $n=6$.

it does not spontaneously produce tau aggregates. We found that oligomers and monomers of tau, intraventricularly injected in hTau mice, determine alterations of tau through different mechanisms. Whereas oligomers mediate the aggregation of tau through a conformational change of the protein, regardless of the action of tau specific kinases, monomers cause a toxic cleavage of tau through calpain activation, leading to the generation of a $17 \mathrm{kDa}$ neurotoxic tau fragment. This tau fragment 
is present in brain areas affected in AD and other tauophaties. Thus, the mechanism underlying the generation of this peptide might be part of a conserved pathological process shared by multiple tauophaties [13].

The location of tau aggregates depends on the different pathologies in which they form. In AD, neurofibrillary lesions first appear in locus coeruleus and enthorinal cortex, then they show in the hippocampal formation and large parts of neocortex $[16,17]$. Tau inclusions follow the opposite direction of $A \beta$ plaques, which form first in the neocortex. The symptoms of $\mathrm{AD}$ are present when both abundant tau inclusions and $A \beta$ deposits are present in the neocortex $[16,17]$. It remains to be determined whether $\mathrm{A} \beta$ plaques and tau inclusions form independently and when they become self-sustaining. It is also not clear whether one type of inclusion influences the others. Here we have found dual effects by either oTau which produces tau conformational changes and mTau which causes calpain-mediated generation of a $17 \mathrm{kDa}$ neurotoxic tau fragment.

We have found that the oTau mediated conformational change of tau is not due to its hyperphosphorylation. This is consistent with the observation that in tauopathies, mutations or polymorphisms of MAPT determine decrease of tubulin binding, or overexpression of identical tau isoforms $[18,19]$. We have also found that monomeric preparations of $A \beta_{1-42}$ are capable of altering tau aggregation when injected in mice with a pure human tau background through activation of phosphokinases as well as impaired tau degradation [2]. A $\beta$ activates phosphokinases that hamper tubulin binding increasing the levels of free tau. As a consequence, tau polymerizes, since tau-tau binding is stronger than tau-tubulin binding [20]. Thus, whether tau hyperphosphorylation in $\mathrm{AD}$ is a cause of aggregation [9] or whether the two changes occur independently is still controversial. Although phosphorylation of tau at given sites can result in the loss of certain tau functions (e.g., tubulin binding), the increase in phosphorylation per $s e$ is not necessarily detrimental, as it occurs also naturally (e.g., in fetal mammalian) [21, 22]. Here we report that oligomers of tau favor conformational changes in endogenous tau when injected intraventricularly in hTau mice determining pathological tau production. It has been demonstrated that enhanced neuronal activity increases release of tau both in vitro $[6,23]$ and in vivo [24] and that released tau exacerbates tau pathology in vivo [25]. Excess of free tau would lead to its oligomerization and induction of tau pathology through conformational changes, as shown by our study.

We have found that injection of hTau mice with mTau increases calpain activity and causes a toxic tau cleavage as demonstrated by the production of a $17 \mathrm{kDa}$ peptide. Previous data indicated that the expression of this fragment in cultured hippocampal neurons leads to their progressive degeneration [26]. Conversely, conditions that prevent the generation of this fragment were followed by enhanced neuronal survival $[27,28]$. Because calpains are a calcium-dependent protease, their dysregulation could be associated with abnormal calcium influx as described in AD [13] and in other tauopathies [7]. Interestingly, the appearance of this $17 \mathrm{kDa}$ fragment is inhibited by calpain inhibitors, suggesting that tau is an in vivo calpain substrate, correlated with disruption of the microtubule network and induction of neuronal apoptosis [29, 30]. Moreover, the soluble dephosphorylated tau fragment of $17 \mathrm{kDa}$ that is unable to associate with microtubules accumulates in the perikarya of dying cells and mediates apoptotic cell death [29, 30]. Collectively, these data indicate that tau cleavage and change in phosphorylation are important early factors in the failure of the microtubule network that occurs during neuronal apoptosis.

Our results contribute to modify the prevailing hypothesis in the AD field that the accumulation of $\mathrm{A} \beta$ in the brain is the primary event that induces neuronal degeneration, the latter characterized by tau pathology and suggest that different conformations of proteins involved in $\mathrm{AD}$ are toxic, independent of the type of the protein. The interval of time between the formation of the first protein inclusions and the appearance of the symptoms may provide a therapeutic window. Understanding the events that lead to the formation of inclusions may offer new approaches for the development of sensitive diagnostic techniques and effective therapies.

\section{ACKNOWLEDGMENTS}

This study was supported by Italian Ministry of Health RF 2010-2305605 project (MT), Regione Piemonte (ET), University of Torino (ET), Compagnia di San Paolo 2013-0929 (MT, GM), Veronesi Foundation (MG), and NIH-NIA grant R01AG049 402 (OA).

Authors' disclosures available online (http://j-alz. com/manuscript-disclosures/17-0298r1). 


\section{REFERENCES}

[1] Morris M, Maeda S, Vossel K, Mucke L (2011) The many faces of tau. Neuron 70, 410-426.

[2] Manassero G, Guglielmotto M, Zamfir R, Borghi R, Colombo L, Salmona M, Perry G, Odetti P, Arancio O, Tamagno E, Tabaton M (2016) Beta-amyloid 1-42 monomers, but not oligomers, produce PHF-like conformation of tau protein. Aging Cell 15, 914-923.

[3] Fontaine SN, Sabbagh JJ, Baker J, Martinez-Licha CR, Darling A, Dickey CA (2015) Cellular factors modulating the mechanism of tau protein aggregation. Cell Mol Life Sci 72, 1863-1879.

[4] Goedert M (2015) Alzheimer's and Parkinson's diseases: The prion concept in relation to assembled $A \beta$, tau, and $\alpha$-synuclein. Science 349, 1255555.

[5] Andorfer C, Kress Y, Espinoza M, de Silva R, Tucker KL, Barde YA, Duff K, Davies P (2003) Hyperphosphorylation and aggregation of tau in mice expressing normal human tau isoforms. J Neurochem 86, 582-590.

[6] Fá M, Puzzo D, Piacentini R, Staniszewski A, Zhang H, Baltrons MA, Li Puma DD, Chatterjee I, Li J, Saeed F, Berman HL, Ripoli C, Gulisano W, Gonzalez J, Tian H, Costa JA, Lopez P, Davidowitz E, Yu WH, Haroutunian V, Brown LM, Palmeri A, Sigurdsson EM, Duff KE, Teich AF, Honig LS, Sierks M, Moe JG, D'Adamio L, Grassi C, Kanaan NM, Fraser PE, Arancio O (2016) Extracellular tau oligomers produce an immediate impairment of LTP and memory. Sci Rep 6, 19393.

[7] Furukawa K, Wang Y, Yao PJ, Fu W, Mattson MP, Itoyama Y, Onodera H, D'Souza I, Poorkaj PH, Bird TD, Schellenberg GD (2003) Alteration in calcium channel properties is responsible for the neurotoxic action of a familial frontotemporal dementia tau mutation. J Neurochem 87, 427-436.

[8] Weaver CL, Espinoza M, Kress Y, Davies P (2000) Conformational change as one of the earliest alterations of tau in Alzheimer's disease. Neurobiol Aging 21, 719-727.

[9] Alonso A, Zaidi T, Novak M, Grundke-Iqbal I, Iqbal K (2001) Hyperphosphorylation induces self-assembly of tau into tangles of paired helical filaments/straight filaments. Proc Natl Acad Sci U S A 98, 6923-6928.

[10] Haase C, Stieler JT, Arendt T, Holzer M (2004) Pseudophosphorylation of tau protein alters its ability for self-aggregation. J Neurochem 88, 1509-1520.

[11] LaFerla FM (2002) Calcium dyshomeostasis and intracellular signalling in Alzheimer's disease. Nat Rev Neurosci 3, 862-872.

[12] Jin N, Yin X, Gu J, Zhang X, Shi J, Qian W, Ji Y, Cao M, Gu X, Ding F, Iqbal K, Gong CX, Liu F (2015) Truncation and activation of dual specificity tyrosine phosphorylationregulated kinase $1 \mathrm{~A}$ by calpain I: A molecular mechanism linked to tau pathology in Alzheimer disease. J Biol Chem 290, 15219-15237.

[13] Ferreira A, Bigio EH (2011) Calpain-mediated tau cleavage: A mechanism leading to neurodegeneration shared by multiple tauopathies. Mol Med 17, 676-685.

[14] Czogalla A, Sikorski AF (2005) Spectrin and calpain: A 'target' and a 'sniper' in the pathology of neuronal cells. Cell Mol Life Sci 62, 1913-1924.

[15] Fernandez-Morales JC, Arranz-Tagarro JA, Calvo-Gallardo E, Maroto M, Padin JF, Garcia AG (2012) Stabilizers of neuronal and mithocondrial calcium cycling as a strategy for developing a medicine for Alzheimer's disease. ACS Chem Neurosci 3, 873-883.
[16] Jack CR Jr, Knopman DS, Jagust WJ, Petersen RC, Weiner MW, Aisen PS, Shaw LM, Vemuri P, Wiste HJ, Weigand SD, Lesnick TG, Pankratz VS, Donohue MC, Trojanowski JQ (2013) Tracking pathophysiological processes in Alzheimer's disease: An updated hypothetical model of dynamic biomarkers. Lancet Neurol 12, 207-216.

[17] Crary JF, Trojanowski JQ, Schneider JA, Abisambra JF, Abner EL, Alafuzoff I, Arnold SE, Attems J, Beach TG, Bigio EH, Cairns NJ, Dickson DW, Gearing M, Grinberg LT, Hof PR, Hyman BT, Jellinger K, Jicha GA, Kovacs GG, Knopman DS, Kofler J, Kukull WA, Mackenzie IR, Masliah E, McKee A, Montine TJ, Murray ME, Neltner JH, SantaMaria I, Seeley WW, Serrano-Pozo A, Shelanski ML, Stein T, Takao M, Thal DR, Toledo JB, Troncoso JC, Vonsattel JP, White CL 3rd, Wisniewski T, Woltjer RL, Yamada M, Nelson PT (2014) Primary age-related tauopathy (PART): A common pathology associated with human aging. Acta Neuropathol 128, 755-766.

[18] Hutton M, Lendon CL, Rizzu P, Baker M, Froelich S, Houlden H, Pickering-Brown S, Chakraverty S, Isaacs A, Grover A, Hackett J, Adamson J, Lincoln S, Dickson D, Davies P, Petersen RC, Stevens M, de Graaff E, Wauters E, van Baren J, Hillebrand M, Joosse M, Kwon JM, Nowotny P, Che LK, Norton J, Morris JC, Reed LA, Trojanowski J, Basun H, Lannfelt L, Neystat M, Fahn S, Dark F, Tannenberg T, Dodd PR, Hayward N, Kwok JB, Schofield PR, Andreadis A, Snowden J, Craufurd D, Neary D, Owen F, Oostra BA, Hardy J, Goate A, van Swieten J, Mann D, Lynch T, Heutink $\mathrm{P}$ (1998) Association of missense and 5'-splice-site mutations in tau with the inherited dementia FTDP-17. Nature 393, 702-705.

[19] Spillantini MG, Murrell JR, Goedert M, Farlow MR, Klug A, Ghetti B (1998) Mutation in the tau gene in familial multiple system tauopathy with presenile dementia. Proc Natl Acad Sci U S A 95, 7737-7741.

[20] Crews L, Masliah E (2010) Molecular mechanisms of neurodegeneration in Alzheimer's disease. Hum Mol Genet 19, R12-20.

[21] Matsuo ES, Shin RW, Billingsley ML, Van deVoorde A, O'Connor M, Trojanowski JQ, Lee VM (1994) Biopsyderived adult human brain tau is phosphorylated at many of the same sites as Alzheimer's disease paired helical filament tau. Neuron 13, 989-1002.

[22] Yu Y, Run X, Liang Z, Li Y, Liu F, Liu Y, Iqbal K, GrundkeIqbal I, Gong CX (2009) Developmental regulation of tau phosphorylation, tau kinases, and tauphosphatases. $\mathrm{J} \mathrm{Neu}$ rochem 108, 1480-1494.

[23] Pooler AM, Phillips EC, Lau DH, Noble W, Hanger DP (2013) Physiological release of endogenous tau is stimulated by neuronal activity. EMBO Rep 14, 389-394.

[24] Yamada K, Holth JK, Liao F, Stewart FR, Mahan TE, Jiang H, Cirrito JR, Patel TK, Hochgräfe K, Mandelkow EM, Holtzman DM (2014) Neuronal activity regulates extracellular tau in vivo. J Exp Med 211, 387-393.

[25] Wu JW, Hussaini SA, Bastille IM, Rodriguez GA, Mrejeru A, Rilett K, Sanders DW, Cook C, Fu H, Boonen RA, Herman M, Nahmani E, Emrani S, Figueroa YH, Diamond M, Clelland CL, Wray S, Duff KE (2016) Neuronal activity enhances tau propagation and tau pathology in vivo. Nat Neurosci 19, 1085-1092.

[26] Park SY, Ferreira A (2005) The generation of a 17 kDa neurotoxic fragment: An alternative mechanism by which tau mediates beta-amyloid-induced neurodegeneration. $\mathrm{J} \mathrm{Neu}$ rosci 25, 5365-5375. 
[27] Park SY, Tournell C, Sinjoanu RC, Ferreira A (2007) Caspase-3- and calpain-mediated tau cleavage are differentially prevented by estrogen and testosterone in betaamyloid-treated hippocampal neurons. Neuroscience 144, 119-127.

[28] Sinjoanu RC, Kleinschmidt S, Bitner RS, Brioni JD, Moeller A, Ferreira A (2008) The novel calpain inhibitor A705253 potently inhibits oligomeric beta-amyloid-induced dynamin 1 and tau cleavage in hippocampal neurons. Neurochem Int 53, 79-88.
[29] Canu N, Dus L, Barbato C, Ciotti MT, Brancolini C, Rinaldi AM, Novak M, Cattaneo A, Bradbury A, Calissano P (1998) Tau cleavage and dephosphorylation in cerebellar granule neurons undergoing apoptosis. J Neurosci 18, 7061-7074.

[30] Canu N, Calissano P (2003) In vitro cultured neurons for molecular studies correlating apoptosis with events related to Alzheimer disease. Cerebellum 2, 270-278. 